\title{
THE DEVELOPMENT OF MANAGEMENT CONTROL AS A NEW PUBLIC MANAGEMENT TOOL - DIAGNOSIS OF POLISH MUNICIPALITIES IN THE LIGHT OF EMPIRICAL RESEARCH
}

\begin{abstract}
Management control in Polish public sector was introduced in 2009. For this purpose management control standards were introduced as a part of changes aiming at a transition from the culture of law enforcement to the culture of achieving results. From this point of view, it is a rather new instrument of the public management in Poland. The introduction of management control standards can be perceived as an experiment as they provide merely a basis for the development of detailed procedures. They are a part of the "soft type" law and thus don't have the character of an act of commonly applicable law. Several years after providing applicable legal solutions, the biggest problem faced by the Polish local government units is still the fact that neither the introduced management control standards nor the literature provide solid theoretical concepts or clear, specific instruments to facilitate the development of customised solutions within the approved law standards. Due to existing gap, the aim of this study is to assess the development and functioning of the management control as well as its impact on current activities undertaken by the local government units in Poland. The conclusions were drawn on the basis of a survey. The study preceded by a pilot launch of the research tool, was conducted with the entire population of Polish municipalities (2 489 units) in the years 2013-2014, and further in-depth studies in 2015. The research revealed that there is a considerable dissonance between the formal implementation of management control and ongoing impact on the current functioning of Polish municipalities.

Keywords: strategic management, management control, New Public Management, local government units, public administration, public management
\end{abstract}

\section{INTRODUCTION}

In the last period there are more and more symptoms of ongoing major socioeconomic changes. Military conflicts in the Middle East, the assault on Ukraine and destabilization of the political situation, embargo to Russia, the growing threat of terrorist attacks, lower rate of growth of China's economy or drastic declines in the market prices of raw materials are examples only helping us realize ever more sweeping changes occurring in today's global environment. The modern world is becoming more complex, dynamic and full of interaction and interdependence ${ }^{2}$. These fundamental changes not

\footnotetext{
${ }^{1}$ Jarosław Ignacy, PhD, Strategic Management Department, Wrocław University of Economy, ul. Komandorska 118/120, 53-345 Wrocław, jaroslaw.ignacy@ue.wroc.pl.

${ }^{2}$ R.M. Grant, Współczesna analiza strategii, Oficyna a Wolters Kluwer business, Warszawa 2011; P.F. Drucker, Praktyka zarzadzania, Wyd. MT Biznes, 2005; R. Krupski, Zarzadzanie przedsiębiorstwem $w$ turbulentnym otoczeniu, PWE, Warszawa 2005.
} 
only affect companies of all sizes $^{3}$, but also local government as well as public administration. Although the tasks of the local administration units and the methods of their realisation are subject to constant transformations, the essence of the activities of local governments that consist in satisfying the local needs remains unchanged. However, it is worth remembering that the confrontation of limited resources of local government units (LGUs) with the unlimited needs of residents must result in an unavoidable conflict since it is not possible to fully satisfy the needs of all members of the local community ${ }^{4}$. Therefore, the fundamental problem is not setting the main goal of activities undertaken by the local government, but searching for the most effective ways to achieve it ${ }^{5}$. This process is crucial from the social point of view and is still topical. Therefore, it requires a continuous search for the best solutions available. In this context, the purpose of this article is to assess the functioning and development of management control as a New Public Management tool for achieving goals and objectives as well as monitoring the degree of their implementation in municipalities in Poland.

\section{MANAGEMENT CONTROL AS A PART OF NEW PUBLIC MANAGEMENT REFORMS - THEORETICAL FRAMEWORK}

Although the history of administration (and later of the public sector) is very rich, the transformations that took place in the recent past had the greatest impact on its today's image $^{6}$. From this perspective, the most significant changes and transformations of the public administration took place in four basic stages of development ${ }^{7}$ :

- stage of "state of law" and administrative law (since the late 18th century) - where public institutions were treated as a tool for executing the law;

- stage of (traditional) Public Administration (since the mid-19th century) - that is an independent apparatus not so much for executing the law but the political decisions behind legal settlements that specify the rules for the application of the law;

- stage of Public Management (including New Public Management, since the early 1980s);

- stage of Public Governance (since the mid-1990s) - an approach to the public sector, especially to the public administration, as to an essential element of the civil society network (in a broader sense), which interacts with members (individuals, groups) of the civil society (in a narrower sense) through appropriate participatory and consultation procedures with stakeholders.

The traditional model of public administration had resisted the impact of time for an extended period of time, but the new social conditions and progressive economic changes

${ }^{3}$ P. Kotler, J.A. Caslione, Chaos. Zarzadzanie i marketing w erze turbulencji, Wyd. New Media, Warszawa 2010, s. 12; T.M. Box, Small firm strategy in turbulent times, "Academy of Strategic Management Journal" 2011, vol. 10, Issue 1, pp. 115-122.

${ }^{4}$ J. Stiglitz, Ekonomia sektora publicznego, Wyd. Naukowe PWN, Warszawa 2010, pp. 69-75, J. Hausner, Zarzadzanie publiczne, WN Scholar, Warszawa 2008.

${ }^{5}$ J. Ignacy, T. Kopyściański, Selection criteria of strategic goals for local governments, "Argumenta Oeconomica" 2011, no. 2 (27), pp. 15-36.

${ }^{6}$ M. Zawicki, Nowe zarzadzanie publiczne, PWE, Warszawa 2011, pp. 16-17.

${ }^{7}$ H. Izdebski, Od administracji publicznej do public governance, ,Zarządzanie Publiczne” 2007, no. 1 . 
in the 1970s exposed many weaknesses of the public administration. The excessive bureaucracy, as well as the low universality and effectiveness of this model of governance, were particularly criticized ${ }^{8}$. Under these conditions, an intensive search for more efficient solutions in the scope of the public sector management was started ${ }^{9}$. The main reasons for undertaking the reforms and for the development of the New Public Management (NPM) can be grouped into three basic categories ${ }^{10}$ : a) growth of the public sector, b) economic and political crisis, c) crisis of the value of the traditional public administration. The conviction that the administration is excessively expanded and that the public sector is involved in too many issues gave an impulse to the development of research on the effective use of available resources. Besides, in developed countries, the effects of recurring recessions of the 1970s and related political crises became more and more noticeable ${ }^{11}$. Therefore, an important argument that encouraged for undertaking reforms of public management was the pressure to reduce taxes and public spending in developed countries, while striving to maintain a high standard of living and high quality of public services ${ }^{12}$. As an effect of these persistent social problems, there appeared the conviction that the traditional model of administration was coming to an end, which resulted in calling into question almost all the assumptions and distinguishing features of this model. This situation has become a strong stimulus for searching for new, more efficient ways of governing. One of the proposed solutions was the market order and the use of achievements of the private sector in management. As a result, the term New Public Management (NPM) was coined ${ }^{13}$. Particularly deep reforms were carried out in New Zealand, Australia, United Kingdom and the United States, but interest in them has also expressed in Canada, Sweden, the Netherlands, other Western European countries, as well as some developing countries ${ }^{14}$.

${ }^{8}$ F. Naschold, C. Otter, Public Sector Transformation. Rethinking Markets and Hierarchies in Government, John Benjamin Publishing Company, Amsterdam, Philadelphia, 1996.

${ }^{9}$ H. Izdebski, Badania nad administracja publiczna, [in:] Administracja publiczna, J. Hausner (ed.), Wyd. Naukowe PWN, Warszawa 2003, pp. 16-17.

${ }^{10}$ M. Zawicki, op. cit., pp. 22-23.

11 J.L. Brudney, L.J. O'Toole, H.G. Rainey (ed.), Advancing Public Management: New Developments in Theory, Methods, and Practice, Georgetown University Press, Washington 2000, pp. 4-6.

12 Ch. Pollitt, G. Bouckaert, Public Management Reform. A Comparative Analysis, Oxford University Press, Oxford 2000, pp. 8-12

${ }^{13}$ C. Hood, Public Administration and Public Policy: Intellectual Challenges for the 1990s., "Australian Journal of Public Administration” 1989, vol. 48, pp. 346-358, C. Hood, A Public Management for All Seasons, "Public Administration" 1991, vol. 69, pp. 3-19, P. Aucoin., Administrative Reform in Public Management: Paradigms, Principles Paradoxes and Pendulums, "Governance" 1990, vol. 3, pp. 115-117.

${ }^{14}$ T. Lubińska (ed.), Nowe zarzadzanie publiczne-skuteczność i efektywność, Wyd. Difin, Warszawa 2009, pp. 255-340, D. Osborne, T. Gaebler, Rządzić inaczej, Wyd. Media Rodzina, 2005, G. Hammerschmid, R.E., Meyer, New Public Management in Austria, "Public Administration" 2005, vol. 83, no. 3, pp. 709-733, K. Mongkol, The Critical Review of New Public Management Model and its Criticisms, "Research Journal of Business Management" 2011, vol. 5 (1), pp. 35-43, R. Kluvers, J. Tippett, The Views of Councillors and Managers on Accountability in Local Government: An Empirical Study in Australia, "International Journal of Management" 2011, vol. 28 , no. 2 , pp. 519-527. 
The NPM reforms were based on several primary assumptions such as ${ }^{15}$ : (i) promoting competition in the area of service delivery, (ii) measuring the activity and focus on results and financial results rather than on inputs, (iii) mission oriented aims and management instead of activities only based on compliance with rules and regulations, (iv) preventing problems by anticipating them. The common denominator of NPM assumptions in the area of public administration was to prioritize the art of management over the art of administration. The new paradigm emphasised the fact that the administration means filling instructions while management means achieving results ${ }^{16}$. Functions of the NPM are therefore convergent with functions of management. According to the theory of management, all these tasks and areas should be covered by control (supervision) activities aimed at improving the effectiveness of the operations of LGUs.

One of the most important instruments that ensure progress in the quality of public management should be management control $^{17}$. In several countries (like New Zealand, Australia, United Kingdom, Sweden, Netherlands, Canada, Denmark) development and implementation of management control procedures are becoming an increasingly important factor for NPM implementation in the public sector ${ }^{18}$. In Poland, the attempt to make up for the lost time in this area was the introduction of new legal and organizational solutions in 2009. In accordance with Art. 68 of the Act of 27 August 2009 on public finance, the management control in units of the public finance sector comprises of all the activities taken to ensure the realization of objectives and tasks in a lawful, effective, prudent and timely manner ${ }^{19}$. In particular, the purpose of the management control is to ensure: compliance of activities with laws and internal procedures; efficiency and effectiveness of activities; reliability of reports; protection of resources; respecting and promoting the principles of ethical behavior; the effectiveness and efficiency of the information flow and risk management. Ensuring the functioning of adequate, efficient and effective management control is the responsibility of commune heads, mayors, presidents of cities, board chairpersons in LGUs, as well as heads of organizational units.

At present, LGUs perform management control based on the standards published in the Official Journal of the Ministry of Finance No. 15 of 2009 divided into five groups ${ }^{20}$ : internal environment, objectives and risk management, control mechanisms, information and communication, monitoring and evaluation. However, under these standards, neither

${ }^{15}$ C. Auriacombe, 2002, Reflections on the New Public Management, Journal of Public administration, vol. 134, No.2

${ }^{16}$ O.E., Huges, Public Management and Administration. An Introduction, The MacMillan Press Ltd., London 1994, p. 60.

${ }_{17}$ T. Lubińska (ed.), Kierunki modernizacji zarządzania w jednostkach samorzadu terytorialnego, Wyd. Difin, Warszawa 2011, p. 353.

${ }^{18}$ OECD, Management Control in Modern Government Administration: Some Comparative Practices, SIGMA Papers, No. 4, OECD Publishing 1996 http://dx.doi.org/10.1787/5kml6gb4gn32en, (access 14.04.2016), D. Otley, K. Soin, Management Control and Uncertainty, Palgrave Macmillan, Basingstoke UK, 2014, I. Grabner, F. Moers, Management control as a system or a package? Conceptual and empirical issues. Account. Orga. Soc. 38, 2013, pp. 407-419, D.S. Bedford, T. Malmi, Configurations of control: An exploratory analysis. Management Accounting Research, 2015, 27, pp. 2-26.

19 A. Gumińska, A. Marchewka-Bartokowiak, B. Szeląg (eds.), Audit and management control. Case Study. Wyd. CeDeWu, Warszawa, 2012, p. 28

${ }^{20}$ T. Lubińska (ed.), Kierunki..., op. cit., pp. 355-362. 
applicable laws nor the current literature of the subject provides clear, detailed instruments that would allow performing the management control ${ }^{21}$. In turn, the experiences associated with the functioning of the local government sector, which are also presented in the literature of the subject, confirm the existence of a vast range of problems that hinder the improvement of the efficiency of the tasks performed ${ }^{22}$.

\section{METHODS}

To yield the necessary theoretical base, the empirical research was preceded by desk research oriented towards systematising the knowledge related to essence and significance of management control as well as historical, cultural factors, and legal and institutional regulations affecting the implementation of management control.

The survey itself, preceded by a pilot launch of the research tool, was conducted with a sample of 2489 Polish municipalities, in the years 2013-2014, and further in-depth studies in 2015. The entire population of municipalities in Poland constituted the respondents' group. Despite the high level of difficulty of the research, thanks to the effort made, as many as 938 surveys were completed. It is the largest-scale study conducted so far concerning the functioning of the management control in Polish municipalities. The sample and the feedback volume must be considered to be vast and sufficient to develop analyses and reports ${ }^{23}$.

Due to the specificity of the target group and the respondents' time constraints, the number of questions was reduced at the design stage while retaining the comprehensiveness and usefulness of the information on the critical issues within the scope of the study. According to this measures, the survey form included only eight questions: four closed, and three open-ended questions. Additionally, the respondents used a 5-grade Likert scale to express the level of their own judgements' conformity with one survey statement.

The contents of the survey concerned mainly the functioning and importance of management control. Apart from it, the study attempted to determine the impact of management control on current activities undertaken by the LGUs in Poland. The conclusions, drawn on the basis of the survey aimed at finding answers to the following questions:

- How municipalities evaluate the usefulness of management control as a tool for improving performance management of LGUs?

- What sources of information were used to develop procedures for management control?

- What are the links between the conclusions of management control and determination of strategic aims of development of the municipality?

- What are the links between the conclusions of management control and budget planning for the coming years?

\footnotetext{
${ }^{21}$ K. Puchacz, Nowe standardy kontroli zarzadczej w jednostkach sektora finansów publicznych, Gdańsk 2010, pp. 17-18; J. Olejniczak, Performance budgeting and performance information in Poland and EU countries. Selected issues, „Nauki o Finansach” 2011, nr 1 (6), pp. 44-55.

${ }^{22}$ T. Lubińska (ed.), Kierunki..., op. cit., pp. 21-51.

${ }^{23}$ E. Babbie, Badania spoteczne w praktyce, Wyd. Naukowe PWN, Warszawa 2004, p. 288.
} 


\section{EVALUATION OF THE FUNCTIONING AND IMPORTANCE OF MANAGEMENT CONTROL IN LOCAL GOVERNMENT UNITS - RESULTS AND DISCUSSION}

Introduction and starting point for the analysis of the operation and the practical significance of management control are the opinions of municipalities on the usefulness of this tool to improve the efficiency of managing LGUs (Figure 1).

\begin{tabular}{|l|c|c|c|c|c|c|c|}
\hline & $\begin{array}{c}\text { Complete } \\
\text { unsuitable } \\
\text { tool }\end{array}$ & $\begin{array}{c}\text { Unsuitable } \\
\text { tool }\end{array}$ & $\begin{array}{c}\text { Rather } \\
\text { unsuitable } \\
\text { tool }\end{array}$ & $\begin{array}{c}\text { Rather } \\
\text { suitable } \\
\text { tool }\end{array}$ & $\begin{array}{c}\text { Suitable } \\
\text { tool }\end{array}$ & $\begin{array}{c}\text { Complete } \\
\text { suitable } \\
\text { tool }\end{array}$ & $\begin{array}{c}\text { No } \\
\text { opinion }\end{array}$ \\
\hline $\begin{array}{c}\text { \% of } \\
\text { answers }\end{array}$ & $8,67 \%$ & $7,99 \%$ & $24,36 \%$ & $28,99 \%$ & $19,07 \%$ & $2,06 \%$ & $8,76 \%$ \\
\hline
\end{tabular}

Figure 1. Declared usefulness of management control for improving performance management in the opinion of Polish municipalities

Source: Own elaboration on the basis of the conducted research.

Analysis of the information obtained during the survey illustrates very high extremes and discrepancies in the evaluation of management control by the Polish municipalities. Extreme opinions are expressed by almost $11 \%$ of municipalities, of which approx. $8.7 \%$ believe that management control is an entirely useless tool. The opposite opinion is expressed only by approx. $2.1 \%$ of municipalities. In this regard, a distinct advantage, therefore, have municipalities, which negatively evaluate the usefulness of management control. The other ratings tend to be more balanced. Almost $8 \%$ of municipalities rated management control as an unsuitable tool while more than $19 \%$ of municipalities in Poland considered it as a useful management tool. The percentage of municipalities evaluating management control as a rather useful or rather useless tool is very similar. A slight advantage is made by municipalities who have found management control as a rather useful tool. The percentage of these municipalities amounted to almost $29 \%$ while almost $24.4 \%$ of the municipalities expressed the opposite opinion. It is worth noting that the overall share of municipalities looking to positively assess the management control amounts to $50,12 \%$. In practice, therefore, it is slightly higher than the percentage of municipalities that negatively evaluate management control. Such opinion was expressed by $41.12 \%$ of the municipalities and $8.76 \%$ had no opinion on this subject. On the one hand, therefore, it is worth noting that a slight advantage of positive feedback regarding management control is expressed by municipalities, but on the other hand, it is important not to ignore the very clear negative signal, indicating a lack of conviction and willingness to implement management control by executives and employees. Research results indicate that often they do not see the need to create mechanisms of management control or do not fully understand its essence. It is worth remembering that those opinions are declarative in nature. Therefore, it is advisable to further explore the functioning and practical importance of management control in the Polish municipalities. In this regard more reliable basis are the answers to the question about the type and nature of the sources of information which served to develop procedures for management control in municipalities in Poland (Figure 2). 




Figure 2. Sources of information used in developing procedures for management control

Source: Own elaboration on the basis of the conducted research.

The conducted studies lead to the conclusion that the governing document forming the basis for the creation of procedures for management control of the surveyed municipalities have become the guidelines resulting from the standards of management control published by the Ministry of Finance. They were used by almost $93 \%$ of the surveyed municipalities. Another relatively frequently used source of information has become the exchange of experience with other national, LGUs. Such actions were undertaken by over $51 \%$ of municipalities in Poland. On this occasion, it is worth noting that at the same time very faint percentage of Polish municipalities benefited from the experience of foreign local governments. Such actions were indicated by as little as $2.5 \%$ of the Polish municipalities. Despite the objective difficulties in reaching foreign LGUs, it should be realised that they can provide a rich and useful information regarding implementation methods of management control. It is mainly due to the fact that foreign LGUs are far more advanced in the process of implementing management control and have worked out 
efficient, practical solutions to challenges in this regard as described in the subject literature $^{24}$.

It is worth noting, that approx. $28.7 \%$ of the surveyed municipalities used the strategy of development as an important basis for creating procedures of management control. Such actions are particularly useful and valuable in the context of determining the objectives and monitoring and evaluating of their implementation. Among other internal documents included in the development of procedures and implementation of management control, the most commonly used were: documentation of the quality management system, e.g., ISO, the statute and other organizational regulations, codes of ethics, internal instructions and various other regulations, among others, periodic evaluation of employees, reports and records of internal audits carried out, the conclusions of external controls (including the Supreme Chamber of Control) and materials from internal and external training sessions and workshops.

Analysis of previously presented responses allows drawing significant conclusions on the functioning and importance of management control in the Polish municipalities. A legal obligation to implement management control system in municipalities forced them to evaluate the previously used procedures for their adaptation to the amended law - the Public Finance Act. An in-depth analysis of the activities of municipalities in the creation of management control system, however, shows that the solution adopted by the municipalities show a very significant similarity which often expresses itself in rewriting the guidelines described in the management control standards published by the Ministry of Finance. Duplicating the mentioned guidelines should be considered as hazardous because of many threads connected with this approach. Particularly striking is a dangerous and widespread lack of detailed regulations on management control system taking into account the legal and financial conditions for the development of the municipality (number of inhabitants, type of municipality, economic and financial situation, development strategy). When creating a management control system, it is important not to forget that the published standards of management control should be only a starting point to develop detailed solutions. The conducted research also confirms that there are still not many municipalities that have developed specific procedures for management control adapted to their specific situation. The functioning and practical importance of management control are determined not only by indicated aspects including the opinions of the municipalities covering the suitability and sources of information used for the creation of management control system. The real litmus test of the progress in the development of management control is its integration with the current activities undertaken by the municipality. The larger impact on current actions have procedures for management control, the greater the chance that it will contribute to the improvement of efficiency regarding setting and implementing long-term goals of LGUs while increasing control over public spending. For the assessment of the development and practical functioning of management control, it is crucial to verify the extent to which the results of the control activities are modifying the strategic objectives of the municipality or

\footnotetext{
${ }^{24}$ N. Berland, B. Dreveton, Management control system in public administration: beyond rational myth, [in:] J.C. Scheid (ed.), Accounting Reform in the Public Sector: Mimicry, Fad or Necessit, Paris 2006, pp. 21-37; A. Shah, Local public financial management, Public sector governance and accountability series, Washington D.C. 2007.
} 
influence the decisions taken in the framework of budget planning for the coming years (Figure 3 and 4).

\section{The impact of management control to update the directions of development of the municipality}

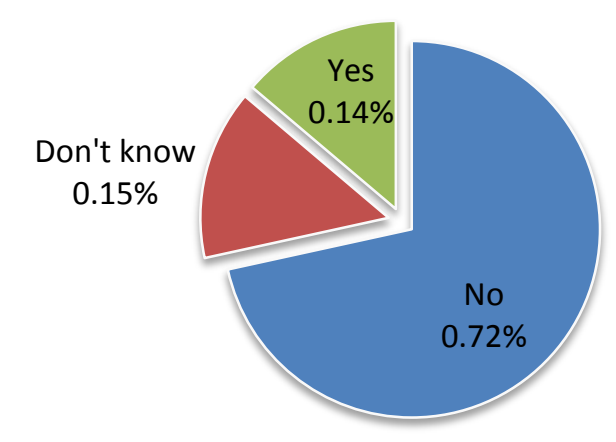

Figure 3. The impact of management control to update the directions of development of the municipality

Source: Own elaboration on the basis of the conducted research.

\section{The impact of management control on budget} planning

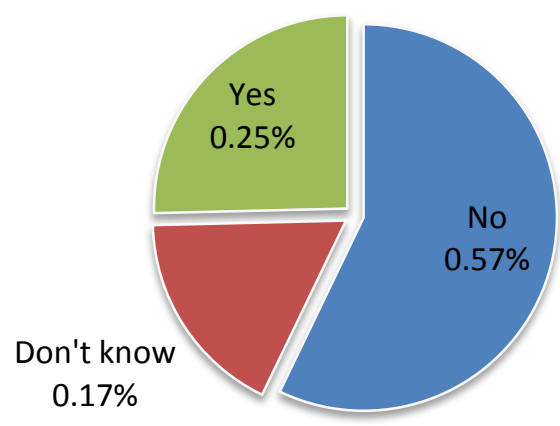

Figure 4. The impact of management control on budget planning for the following years Source: Own elaboration on the basis of the conducted research. 
During the analysis of the presented results of the research, it is hard to resist the impression that the management control procedures are poorly integrated with the current activities undertaken by the municipalities. The results confirm the presence of a disturbing phenomenon, consisting in the fact that management control is usually restricted to the role of another bureaucratic procedure. The responses confirm that in the vast majority of municipalities management control does not have a major impact on the functioning of the municipality. The responses evidence this approach. There is a small percentage of municipalities that declare the use of audit conclusions of management control in the development of future budgets (a little over 25\%). Interestingly, an even more difficult situation occurs concerning the impact of management control on adjusting the development strategy and updating strategic directions of development. Such links are confirmed only by less than $14 \%$ of municipalities in Poland. Conducted studies confirm that the functioning of management control in the vast majority of municipalities is detached from current activities both regarding the budget and updates of the development strategy. It is worth noting, however, that in such case is it difficult to expect an improvement in the efficiency of the management of the municipality and an increase in the efficiency of budget spending. The conducted research indicates that the imperfections and practical problems with the management control revealed by the study are mainly the results of negligence in the development of standards for management control and lack of adjustments to the specifics of a given municipality. These difficulties are particularly clear and troublesome in the area of goal setting, risk management as well as monitoring and evaluation activities. The research indicates that the main problem is the difficulty of the designation of targets associated with the procedures for implementing the tasks, and especially the lack of adequate measures aimed at documenting the results of management control. In practice, the need for preparing reports on the implementation of the objectives and tasks to be implemented in a given year is often neglected. However, such documents could provide additional important information necessary for budget planning, as well as for verification of long-term goals of the municipality. In practice, this function is not met by a statement of management control published by most Polish municipalities. The conducted research confirms that this document is mostly a subjective declaration of the head of the unit, not taking into account a list of the actual activities undertaken in the implementation of management control ${ }^{25}$.

Summing up the discussion on the functioning and practical importance of management control in municipalities in Poland, it is worth noting that a few years after the introduction of the legal obligation of the management control it still remains one of the least recognised tasks imposed on local government administration. At present, in this organisational and legal form, management control is an exhaustive list of acceptable solutions, which encourages municipalities to conduct experiments with implementation tools and procedures on their own. The results of empirical studies, however, negatively assess the effectiveness of such an approach. It turns out that in practice the lack of clear and transparent interpretation of what is and what should be the management control means that apart from not many proven and effective solutions for its implementation,

\footnotetext{
${ }^{25}$ J. Ignacy, T. Kopyściański, Functioning of the second level management control in light of the declarations submitted by the Polish local self-government bodies, "Littera Scripta" 2014, 7 (1), pp. 39-49.
} 
much more widespread are solutions which are distorting the thrust of management control. The research results indicate very limited effects of management control on the functioning of municipalities in Poland.

\section{CONCLUSIONS}

The introduction of management control in the context of the reform of public finances is one of the manifestations of the changes that can be described as the transition from the culture of law enforcement to the culture of achieving results. For this purpose, management control standards were introduced. Their experimental nature lies in the fact that they do not have the character of an act of commonly applicable law, as they are part of the "soft type" law and are not absolute. Therefore, they are not ready-made, universal solutions suitable for every municipality. In this respect, they can be considered rather as good practice cases as they provide merely a basis for the development of detailed procedures. The lack of full understanding of the intervention logic among the surveyed municipalities in Poland leads to serious problems. The most important of them are:

- the significant dissonance between the formal implementation of management control and its actual impact on the functioning of municipalities;

- in practice, management control in Polish municipalities is based on general standards, which are not adapted to the specifics of a given municipality;

- (Exact adherence) Reproduction of the guidelines contained in the standards is a manifestation of the dominant culture of law enforcement over the culture of achieving results;

- functioning for several years, management control has so far usually failed to initiate common factual and organisational changes aimed at improving the quality of public management (as part of the reform trends of NPM);

- -limited effects the functioning of the management control compared to the theoretical foundations and practical experience of other countries.

The research confirms that there is a very clear dissonance between the formal implementation of management control and its actual impact on the functioning of Polish municipalities. Its manifestation is, among others, low level or even no use of the results and conclusions of management control to update the strategic objectives or at least to plan the following municipal budgets. The obligation to develop and implement procedures for management control is extensively regarded as a separate, legally imposed task which has to be executed. These activities are rarely accompanied by wider reflection which includes an analysis of the benefits which can be achieved by comprehensive application of individualised procedures. This approach leads to a specific paradox. On the one hand, the internal regulations of municipalities on management control almost exactly replicate the guidelines set out in the standards, and on the other hand, representatives of local government stress that unclear and ambiguous nature of the standards is one of the main barriers to implementation and functioning of management control. In practice, entities obliged to implement the management control usually prefer to use the vague general guidelines that allow meeting the formal requirement than selfdevelop customised solutions appropriate to the specific needs and local conditions for the functioning of the municipality. 
When analysing the relationships and regularities, it is advisable to keep in mind the unavoidable limitation of the research. They are intimately linked to the nature of the conducted research. The responses reflected the views and opinions of respondents but due to the size of the population it, was not possible to verify them in agreement with available source materials and documents. Another certain limitation is that in the investigation it is impossible to avoid a certain amount of subjectivity associated among others with the interpretation and understanding of statements and research questions. However, it should be emphasised that these inevitable limitations do not nullify the essence and meaning of the conducted study and identified empirical regularities.

Practical problems and difficulties associated with the operation of management control mean that it is important to provide stable theoretical concepts to facilitate the development of customised solutions for management control in municipalities. Representatives of municipalities confirm that very noticeable is the lack of detailed guidelines for the functioning of the management control and formalisation of monitoring the effects of management control in the context of the objectives of the local government. From a practical point of view, it is crucial, therefore, to search for instruments to achieve consistency between the strategic objectives and current activities. Another significant challenge is to define the conditions conducive to satisfying the needs of local communities by increasing the effectiveness of achieving long-term goals in connection with the rationalisation of current expenditures. These aspects should constitute directions for further research on the management control.

The results of the study confirm the fact that the current approach to the standards and functioning of management control has not allowed initiating actual and organisational changes aimed at improving the effectiveness of activities in line with the expectations of the initiator of the changes which is the Ministry of Finance. The conducted research confirms that in the municipalities the culture of law enforcement dominates over the culture of achieving results characteristic for New Public Management.

\section{REFERENCES}

[1] Aucoin P., Administrative Reform in Public Management: Paradigms, Principles Paradoxes and Pendulums, "Governance" 1990, vol. 3.

[2] Auriacombe C., Reflections on the New Public Management, "Journal of Public administration" 2002, vol. 134, no. 2.

[3] Babbie E., Badania społeczne w praktyce, Wyd. Naukowe PWN, Warszawa 2004.

[4] Bedford D.S., Malmi T., Configurations of control: An exploratory analysis. Management Accounting Research, 2015, 27.

[5] Berland N., Dreveton B., Management control system in public administration: beyond rational myth, [in:] Scheid J.C. (ed.), Accounting Reform in the Public Sector: Mimicry, Fad or Necessit, Paris 2006.

[6] Box T.M., Small firm strategy in turbulent times. "Academy of Strategic Management Journal" 2011, vol. 10, Issue 1.

[7] Brudney J.L., O’Toole L.J., Rainey H.G. (ed.), Advancing Public Management: New Developments in Theory, Methods, and Practice, Georgetown University Press, Washington 2000. 
[8] Drucker P.F., Praktyka zarzadzania, Wyd. MT Biznes, 2005.

[9] Grabner I., Moers F., Management control as a system or a package? Conceptual and empirical issues. Account. Orga. Soc. 38, 2013.

[10] Grant R.M., Wspótczesna analiza strategii, Oficyna a Wolters Kluwer business, Warszawa 2011.

[11] Gumińska A., Marchewka-Bartokowiak A., Szeląg B. (eds.), Audit and management control. Case Study, Wyd. CeDeWu, Warszawa 2012.

[12] Hammerschmid G., Meyer R.E., New Public Management in Austria, "Public Administration" 2005, vol. 83, no. 3.

[13] Hausner J., Zarządzanie publiczne, Wyd. Naukowe Scholar, Warszawa 2008.

[14] Hood C., A Public Management for All Seasons, "Public Administration" 1991, vol. 69 .

[15] Hood C., Public Administration and Public Policy: Intellectual Challenges for the 1990s., "Australian Journal of Public Administration” 1989, vol. 48.

[16] Huges O.E., Public Management and Administration. An Introduction, The MacMillan Press Ltd., London 1994.

[17] Ignacy J., Kopyściański T., Functioning of the second level management control in light of the declarations submitted by the Polish local self-government bodies, "Littera Scripta" 2014, 7 (1).

[18] Ignacy J., Kopyściański T., Selection criteria of strategic goals for local governments, "Argumenta Oeconomica" 2011, no. 2 (27).

[19] Izdebski H., Badania nad administracja publiczna, [in:] J. Hausner (ed.), Administracja publiczna, Wyd. Naukowe PWN, Warszawa 2003.

[20] Izdebski H., Od administracji publicznej do public governance, „Zarządzanie Publiczne" 2007, nr 1.

[21] Kotler P., Caslione J.A., Chaos. Zarzadzanie i marketing $w$ erze turbulencji, New Media, Warszawa 2010.

[22] Kluvers R., Tippett J., The Views of Councillors and Managers on Accountability in Local Government: An Empirical Study in Australia, "International Journal of Management" 2011, vol. 28, no. 2.

[23] Krupski R., Zarzadzanie przedsiębiorstwem $w$ turbulentnym otoczeniu, PWE, Warszawa 2005.

[24] Lubińska T. (ed.), Kierunki modernizacji zarządzania $w$ jednostkach samorzadu terytorialnego, Wyd. Difin, Warszawa 2011.

[25] Lubińska T. (ed.), Nowe zarządzanie publiczne - skuteczność i efektywność, Wyd. Difin, Warszawa 2009.

[26] Mongkol K., The Critical Review of New Public Management Model and its Criticisms, "Research Journal of Business Management" 2011, vol. 5 (1).

[27] Naschold F., Otter C., Public Sector Transformation. Rethinking Markets and Hierarchies in Government, John Benjamin Publishing Company, Amsterdam, Philadelphia, 1996. 
[28] OECD, Management Control in Modern Government Administration: Some Comparative Practices, SIGMA Papers, no. 4, OECD Publishing 1996, http://dx.doi.org/10.1787/5kml6gb4gn32-en.

[29] Olejniczak J., Performance budgeting and performance information in Poland and EU countries. Selected issues, „Nauki o Finansach” 2011, nr 1 (6).

[30] Osborne D., Gaebler T., Rządzić inaczej, Wyd. Media Rodzina, 2005.

[31] Otley D., Soin K., Management Control and Uncertainty. Palgrave Macmillan, Basingstoke UK, 2014.

[32] Puchacz K., Nowe standardy kontroli zarzadczej w jednostkach sektora finansów publicznych, Gdańsk 2010.

[33] Pollitt Ch., Bouckaert G., Public Management Reform. A Comparative Analysis, Oxford University Press, Oxford 2000.

[34] Shah A., Local public financial management, Public sector governance and accountability series, Washington D.C. 2007.

[35] Stiglitz J., Ekonomia sektora publicznego, Wyd. Naukowe PWN, Warszawa 2010.

[36] Zawicki M., Nowe zarzadzanie publiczne, PWE, Warszawa 2011.

\section{ROZWÓJ KONTROLI ZARZĄDCZEJ JAKO NARZEDZIA NEW PUBLIC MANAGEMENT (NOWEGO ZARZĄDZANIA PUBLICZNEGO) - DIAGNOZA POLSKICH GMIN W ŚWIETLE BADAŃ EMPIRYCZNYCH}

Kontrola zarządcza w Polsce została wprowadzona w 2009 roku. Opublikowane standardy kontroli zarządczej stanowiły część zmian mających na celu przejście od kultury egzekwowania prawa do kultury osiągnięcia wyników. Wprowadzenie standardów kontroli może być postrzegane jako swoisty eksperyment, ponieważ nie stanowią one gotowych, uniwersalnych rozwiązań, a są jedynie podstawą do opracowania szczegółowych procedur przez każdą z gmin. Nie mają charakteru aktu prawa powszechnie obowiązującego, są natomiast normami typu soft law. Kilka lat po wprowadzeniu stosownych rozwiązań prawnych, największym problemem dla polskich gmin jest nadal fakt, że ani wprowadzone standardy kontroli zarządczej, ani literatura przedmiotu nie wskazują stabilnych podstaw koncepcyjnych i jasnych, konkretnych instrumentów, które ułatwiają rozwój niestandardowych rozwiązań w ramach zatwierdzonych standardów prawnych. Ze względu na istniejącą lukę, celem niniejszego opracowania jest analiza rozwoju i funkcjonowania kontroli zarządczej, a także jego wpływu na bieżące działania podejmowane przez gminy w Polsce. Badania, poprzedzone pilotażem narzędzia badawczego, przeprowadzono na całej populacji polskich gmin (obejmującej 2489 jednostek) w latach 2013-2014, a pogłębione badania miały miejsce w 2015 roku. Badania wykazały, że istnieje znaczny dysonans pomiędzy formalnym wdrożeniem kontroli zarządczej a jej realnym wpływem na bieżące funkcjonowanie polskich gmin. Odpowiedzi ankietowanych potwierdzają, że kontrola zarządcza jest nadal często traktowana jako odrębne, narzucone ustawowo zdanie, które należy wykonać. Praktycznym efektem takiego podejścia jest fakt, że większość gmin nie wykorzystuje wyników kontroli zarządczej przy aktualizacji celów strategicznych czy przynajmniej planowaniu kolejnych budżetów gminy. Wyniki badań ankietowych potwierdzają, że obecne podejście do standardów i funkcjonowania kontroli zarządczej nie pozwoliło na zainicjowanie faktycznych i organizacyjnych zmian mających na celu poprawę 
efektywności działań gmin zgodnie z oczekiwaniami inicjatora zmian tzn. Ministerstwa Finansów. Przeprowadzone badania wskazują, że w większości polskich gmin kultura stosowania reguł prawa wciąż dominuje nad kultura osiągania wyników charakterystyczną m.in. dla reform New Public Management.

Słowa kluczowe: zarządzanie strategiczne, kontrola zarządcza, New Public Management (Nowe Zarządzanie Publiczne), jednostki samorządu terytorialnego, administracja publiczna, zarządzanie publiczne.

DOI:10.7862/rz.2016.hss.65

Przestano do redakcji: wrzesień $2016 r$. Przyjęto do druku: grudzień 2016 r. 